\title{
PENGEMBANGAN LECTORA DALAM PEMBELAJARAN TEMATIK - INTEGRATIF UNTUK MENINGKATKAN PRESTASI BELAJAR KOGNITIF DAN KARAKTER SISWA SEKOLAH DASAR
}

\author{
Denty Windarny dan Ali Mustadi \\ Universitas Negeri Yogyakarta \\ Email: dentywindarny@gmail.com
}

\begin{abstract}
Abstrak: Penelitian ini bertujuan menghasilkan multimedia lectora pada pembelajaran tematik-integratif untuk meningkatkan prestasi belajar kognitif siswa serta membangun karakter tanggung jawab dan disiplin bagi siswa kelas IV SD Grogol, Bantul. Penelitian pengembangan ini mengacu langkah yang dikembangkan oleh Borg and Gall. Desain pengembangan dikelompokkan atas empat prosedur pengembangan, yaitu: (1) eksplorasi; (2) pengembangan produk; (3) uji coba dan revisi; dan (4) validasi akhir. Subjek uji coba terbatas adalah 6 siswa kelas IV dan 1 guru kelas SDN Grogol. Subjek uji coba lapangan yaitu 12 siswa dan 1 guru kelas IV. Subjek uji coba operasional 46 siswa, yaitu 22 siswa dari kelas IVA sebagai kelas eksperimen dan 24 siswa dari kelas IVB sebagai kelas kontrol serta 2 guru kelas IVA dan IVB. Analisis data menggunakan pengujian t-test dengan taraf signifikansi 0,05 . Hasil penelitian menunjukkan bahwa multimedia lectora menurut ahli media dan ahli materi berkategori "sangat baik". Respons guru dan siswa terhadap penggunaan multimedia lectora berkategori "baik". Rata-rata skor ketercapaian prestasi belajar secara kognitif dan afektif juga mengalami perbedaan antara kelas eksperimen yang memiliki nilai yang lebih baik dari kelas kontrol. Hal ini dapat dilihat dari perbedaan yang signifikan pada efektivitas pembelajaran sebelum dan sesudah menggunakan multimedia lectora.
\end{abstract}

Kata Kunci: multimedia pembelajaran lectora, tematik-integratif, prestasi belajar, karakter tanggung jawab, dan karakter disiplin

\section{DEVELOPING LECTORA ON THEMATIC - INTEGRATIVE LEARNING TO INCREASE COGNITIVE ACHIEVEMENT AND CHARACTER FOR STUDENT OF ELEMENTARY SCHOOL}

\begin{abstract}
This study aims to produce lectora multimedia on thematic-integrative learning to increase cognitive achievement and responsibility and discipline character at fourth grade students of SDN Grogol. This development research study refers to the model suggested by Borg and Gall. The developmental design was gropes into four developmental procedures, consisting of: (1) explanation; (2) the development of the product; (3) product testing and revisions; and (4) the final validation. The limited try out subjects are 6 students of fourth grade of SDN Grogol and the teacher. The field testing subjects consisted of 12 fourth grade students and the teacher class of fourth grade. The subjects of operational product testing are 46 students consist of 22 students of class IVA and 24 students of class IVB of SDN Grogol and two teachers of grade four.The data were analyzed using t-test with a significance level of 0.05 .The result show that lectora multimedia in offerings according to media expert and material expert is categorized "very good". The responses of teacher and students is categorized "good". The average of learning cognitive achievement and affective achivement, there were significant differences between the experimental class which have value better than control class. It can be seen from the effectiveness of learning before and after using lectora multimedia.
\end{abstract}

Keywords: learning multimedia of lectora, thematic-integrative, academic achievement, responsibility character, and discipline character 


\section{PENDAHULUAN}

Undang-Undang Nomor 20 Tahun 2003 tentang Sistem Pendidikan Nasional Pasal 3 menyatakan fungsi pendidikan nasional adalah untuk mengembangkan kemampuan dan membentuk watak serta peradaban bangsa bermartabat dalam rangka mencerdaskan kehidupan bangsa, bertujuan untuk berkembangnya potensi peserta didik menjadi manusia yang beriman dan bertakwa kepada Tuhan Yang Maha Esa, berakhlak mulia, sehat, berilmu, cakap, kreatif, mandiri, dan menjadi warga negara demokratis serta bertanggung jawab (Kemendiknas, 2013). Untuk melaksanakan fungsi pendidikan tersebut, pendidikan dasar merupakan dasar bagi siswa untuk mengembangkan segala potensi yang dimiliki. Sekolah merupakan tempat individu untuk menemukan, mencari, dan mengaktualisasikan apa yang ada pada dirinya dengan memperhatikan norma, nilai dan aturan yang berlaku di lingkungan.

Tujuan pendidikan adalah membentuk manusia ideal yang memiliki ilmu pengetahuan dan dapat mengimplementasikan ke dalam kehidupan sehari-hari serta memiliki karakter yang baik dalam berperilaku dan hidup baik dalam lingkungannya. Pemahaman siswa terhadap pengetahuan dapat dilihat melalui prestasi belajar kognitif sedangkan perilaku yang baik dapat dibentuk melalui pembentukan karakter yang baik. Benyamin Bloom dalam Sujana (2013:22), menyatakan bahwa klasifikasi prestasi belajar yang merupakan hasil belajar siswa dibagi ke dalam tiga ranah, yaitu ranah kognitif, afektif, dan psikomotorik. ketiga ranah tersebut diharapkan dapat dicapai oleh setiap individu selama proses pembelajaran berlangsung.

Saat ini kurikulum pendidikan di negara kita menerapkan Kurikulum 2013 yang menggunakan metode pembelajaran tema- tik-integratif. Apriani \& Wangid (2015:2), menyebutkan bahwa tematik-integratif penting untuk dilaksanakan karena mampu meningkatkan soft skill dan hard skill siswa berdasarkan proses pembelajarannya yang aktif, menarik, dan bermakna. Pernyataan tersebut juga memberi arti bahwa pembelajaran tematik-integratif memberi peluang besar bagi guru untuk mengembangkan tiga kompetensi yaitu pengetahuan, sikap, dan keterampilan yang berujung pada pribadi manusia yang memiliki good character.

Aspek kognitif atau pengetahuan merupakan kemampuan siswa dalam menyerap informasi atau pengetahuan yang didapatkan selama pembelajaran berlangsung. Kemampuan kognitif siswa dapat dilihat dari seberapa jauh siswa memahami suatu informasi dan menganalisis informasi tersebut. Ketercapaian aspek kognitif ini dapat diketahui melalui tes prestasi belajar yang diberikan sesuai dengan tujuan atau kompetensi. Tidak hanya aspek kognitif saja, aspek sikap atau afektif juga penting dalam pencapaian prestasi belajar siswa. Berita tentang kenakalan anak-anak usia sekolah dasar sering muncul di media massa cetak maupun elektonik. Anak-anak mulai melakukan kenakalan baik di sekolah maupun di luar sekolah. Berdasarkan penelitian Nugroho (2009) perbandingan dan persentasi tindak pidana yang dilakukan pelajar Kabupaten Bantul dapat dilihat pada Tabel 1.

Tabel 1 menunjukkan bahwa kenakalan remaja pada tingkat pendidikan dasar (sekolah dasar dan sekolah menengah pertama) menempati peringkat teratas. Hal ini memperlihatkan sangat minimnya penanaman nilai-nilai karakter dalam proses pendidikan. Guru sebagai pendidik diharapkan mampu menumbuhkan karakter positif di dalam diri siswa. Turunnya moral anak merupakan dampak dari gagalnya 
ketercapaian prestasi belajar dari segi aspek afektif.

Tabel 1. Perbandingan dan Persentasi Tindak Pidana yang Dilakukan Pelajar Kabupaten Bantul

\begin{tabular}{lcc}
\hline No. Tingkat Pendidikan & Jumlah & Persentasi \\
\hline 1. Tidak Sekolah & 1 & $0,38 \%$ \\
2. Sekolah Dasar (SD) & 79 & $29,70 \%$ \\
3. Sekolah Menengah & 133 & $50,00 \%$ \\
Pertama & & \\
4. Sekolah Menengah & 18 & $6,77 \%$ \\
Atas & 35 & $13,16 \%$ \\
5. Sarjana Muda & - & - \\
6. Sarjana & - & - \\
7. Lain-lain & 266 & $100 \%$ \\
\hline Jumlah &
\end{tabular}

Menurut Schunk (2008:2) menyebutkan, "learning is an enduring in behavior, or in the capacity to behave in a given fashion, which results from practice or other forms of experience". Belajar merupakan perubahan tingkah laku yang permanen dalam diri, serta terjadi karena pengalaman yang dialami oleh individu. Prestasi belajar banyak diartikan sebagai seberapa jauh hasil yang telah dicapai siswa dalam penguasaan materi pelajaran yang diterima dalam jangka waktu tertentu. Prestasi belajar pada umumnya dinyatakan dalam angka atau huruf sehingga dapat dibandingkan dengan satu kriteria. Penilaian prestasi belajar digunakan untuk mengetahui hasil capaian dari pembelajaran baik berupa tes maupun pengamatan atau laporan.

Nilai karakter pada diri siswa juga diharapkan muncul dalam diri siswa. Nilai karakter ini sebagai bentuk dari nilai afektif siswa. Zuchdi, et al. (2009:26) nilai-nilai dasar yang perlu dikembangkan dalam pendidikan karakter, yaitu (1) taat beribadah; (2) jujur; (3) bertanggung jawab; (4) disiplin; (5) memiliki etos kerja; (6) mandiri; (7) sinergis; (8) kritis; (9) kreatif dan inovatif; (10) visioner; (11) kasih sayang dan perila- ku; (12) ikhlas; (13) adil; (14) sederhana; (15) nasionalisme; dan (16) internasionalisme.

Yani (2013:164) berpendapat bahwa nilai tanggung jawab adalah sikap dan perilaku seseorang untuk melaksanakan tugas dan kewajibannya, yang seharusnya dia lakukan, terhadap diri sendiri, masyarakat, lingkungan (alam, sosial, dan budaya), negara, dan Tuhan Yang Maha Esa. Tanggung jawab berarti bahwa orang tidak boleh mengelak, bila diminta penjelasan tentang perbuatannya (Bertens, 2005:125). Karakter disiplin ini erat kaitannya dengan karakter tanggung jawab karena di dalam diri siswa yang memiliki karakter tanggung jawab yang kuat akan memunculkan sikap disiplin terhadap dirinya sendiri maupun terhadap orang lain. Disiplin memiliki peranan yang penting dalam perkembangan siswa. Hamedoglu, et.al. (2012:503) menyebutkan, "Discipline is one of the most important parts of education, thus new generation knows, and learns their responsibilities; their bounds for social peace; where and how to behave with their own free will". Disiplin merupakan salah satu bagian yang paling penting dari pendidikan, siswa tahu apa yang harus dilakukan dan belajar memiliki tanggung jawab; memahami batas sosial mereka di mana dan bagaimana mereka harus berperilaku.

Dalam Kurikulum 2013, pembelajaran tematik dimaknai sebagai pembelajaran yang dirancang dan dikemas berdasarkan tema-tema tertentu. Dalam pembahasannya tema-tema ditinjau dari berbagai mata pelajaran. Tema ini menjadi alat pemersatu materi yang beragam dari berbagai mata pelajaran. Yang (2009:162) memperkuat pendapat tersebut dengan pernyataannya, "Theme-based teaching is an approach in which different areas of the curriculum are integrated instead of being separated into different subjects". Artinya, di dalam pembelajaran yang 
berbasis tema ini melaksanakan pembelajaran yang diintegrasikan menjadi satu, bukan dipisahkan ke dalam mata pelajaran yang berbeda. Selanjutnya, tematik tersebut diintegrasikan atau dipadukan. Model terintegrasi (integrated) merupakan pemaduan sejumlah topik dari mata pelajaran yang berbeda, tetapi esensinya sama dalam sebuah topik tertentu. Topik evidensi yang semula terdapat dalam mata pelajaran Matematika, Bahasa Indonesia, Pengetahuan Alam, dan Pengetahuan Sosial, agar tidak membuat muatan kurikulum berlebihan cukup diletakkan dalam mata pelajaran tertentu, misalnya Pengetahuan Alam (Fogarty, 1991:75).

Perkembangan zaman pada abad ke21 ini, tampaknya media elektronik baik visual, audio, dan audio visual akan menjadi pilihan menarik bagi para pendidik dalam menunjang proses pembelajaran baik di dalam kelas maupun di luar kelas. Fanny \& Suardiman (2013:2) menjelaskan bahwa guru tidak bisa lagi berperan sebagai satusatunya sumber informasi bagi kegiatan pembelajaran para siswa. Oleh karena itu, guru membutuhkan media yang bisa dimanfaatkan sebagai sumber informasi alternatif. Media pembelajaran ini menjadi kebutuhan dalam memaksimalkan proses pembelajaran karena dapat meningkatkan efektivitas komunikasi dan interaksi antara pendidik dengan siswa (Uno \& Lamatenggo, 2010:122).

Lectora sebagai multimedia didesain sedemikian rupa dengan memperhatikan karakter siswa. Pendapat dari DeJong, Specht, \& Koper (2008:41) “Therefore, elearning infrastructures that focus on lifelong learning should integrate both formal and informal learning support". Multimedia e-learning ini difokuskan pada pembelajaran yang bermanfaat sepanjang hayat karena lectora merupakan perangkat lunak yang memung- kinkan seorang individu atau kelompok untuk dengan mudah membuatkonten interaktif yang dapat digunakan sebagai situs web internet dan atau aplikasi mandiri CDROM. Menurut Fredy dan Sunarto (2013: 165) multimedia ini merupakan kombinasi dari berbagai unsur media yang terdiri dari teks, gambar, animasi, audio, dan video untuk memperjelas materi. Untuk itu, pembuatan media pembelajaran dengan menggunakan multimedia lectora lebih mudah dibandingkan dengan media berbasis multimedia yang lain. Menu pada multimedia lectora sangat mudah digunakan terutama bagi pendidk yang sudah tidak asing dengan penggunaan komputer. Menu File, Edit, Add, Layout, Tools, Mode, Publish, View, dan Help cara bekerjanya mirip dengan Program Microsoft Office sehingga pengguna multimedia lectora tidak akan menemui kesulitan dalam mengoperasikan media ini.

\section{METODE}

\section{Jenis Penelitian}

Jenis penelitian ini adalah penelitian dan pengembangan atau Research and Developement (R\&D). Pengembangan dilakukan mengacu pada model pengembangan Borg \& Gall. Ada sepuluh langkah dalam penelitian dan pengembangan model Brog \& Gall (1983:775). Desain tersebut kemudian dimodifikasi atas empat tahapan pengembangan, yaitu: (1) eksplorasi, yaitu mengumpulkan informasi dan melakukan penelitian awal melalui studi pustaka, analisis kebutuhan, wawancara, observasi, dan penyusunan instrumen penelitian; (2) pengembangan produk awaldan penilaian ahli yang dilakukan oleh ahli materi dan ahli media; (3) uji coba produk dan revisi; dan (4) validasi akhir berupa perbaikan produk hingga dihasilkan produk akhir 
berupa multimedia lectora untuk pembelajaran tematik-integratif.

\section{Desain Uji Coba Produk}

Uji coba yang dilakukan meliputi tiga tahapan, yaitu: (1) uji coba terbatas; (2) uji coba lapangan; dan (3) uji coba produk operasional. Desain uji coba terbatas menggunakan One-Shot Case Study Design. Desain uji coba lapangan menggunakan OneGroup Pretest-Posttest Design, dan uji coba operasional menggunakan Design Quasy Experiment.

\section{Subjek Penelitian}

Subjek coba dalam penelitian dan pengembangan ini adalah siswa dan guru di SD N Grogol, yaitu sebagai berikut. Uji coba terbatas: 6 siswa kelas IV dan satu guru kelas IV. Uji coba lapangan adalah 12 siswa kelas IV dan satu guru kelas IV. Pada uji coba produk operasional, subjek coba adalah dua kelas yaitu kelas IVA sebagai kelas kontrol dengan siswa berjumlah 24 siswa dan kelas IVB sebagai kelas eksperimen yang berjumlah 22 siswa, serta dua guru kelas IV.

\section{Teknik dan Instrumen Pengumpulan Data}

Teknik pengumpulan data yang digunakan adalah wawancara terstruktur, angket penilaian produk dari ahli dan gu$\mathrm{ru}$, tes prestasi belajar, pengamatan/observasi, serta angket respons guru dan respons siswa. Instrumen yang digunakan dalam pengumpulan data dari penelitian ini berupa pedoman wawancara, lembar penilaian untuk ahli materi dan ahli media, lembar pengamatan atau observasi siswa, angket respons siswa, dan guru.

\section{Teknik Analisis Data}

Langkah-langkah analisis data kelayakan multimedia lectora dilakukan de- ngan tabulasi semua data yang diperoleh dari validator dan butir penilaian yang tersedia dalam instrumen penilaian. Skor total yang diperoleh kemudian diubah menjadi nilai dengan kriteria skala lima dengan kategori, yaitu sangat baik (5), baik (4), kurang baik (3), baik (2), sangat kurang baik (1). Selanjutnya skor dikonversikan ke dalam skala lima dengan rumus seperti pada Tabel 2.

Tabel 2. Konversi Interval Rerata Skor Menjadi Kriteria

\begin{tabular}{clc}
\hline Nilai & \multicolumn{1}{c}{ Interval skor } & Kategori \\
\hline A & $X>X_{i}+1,8$ Sbi & Sangat Baik \\
B & $X_{i}+0,6$ Sbi $<X \leq X_{i}+1,8$ Sbi & Baik \\
C & $X_{i}-0,6 S b i<X \leq X_{i}+0,6$ Sbi & Cukup Baik \\
D & $X_{i}-1,8$ Sbi $<X \leq X_{i}-0,6$ Sbi & Kurang Baik \\
E & $X \leq X_{i}-1,8$ Sbi & Tidak Baik \\
\hline
\end{tabular}

Keterangan:

Xi : Mean $/$ rerata = $1 / 2$ (skor maksimum + skor ideal skor minimun)

Sbi : Simpangan baku $=1 / 6($ skor maksimum ideal skor minimum)

X : Skor yang diperoleh

Penetapan nilai kelayakan produk lectora yang dikembangkan minimal mendapatkan nilai "B" dengan kriteria "Baik".

Keefektifan produk yang dihasilkan dianalisis dengan menggunakan desain quasy experiment. Uji prasyarat yang dilakukan adalah uji normalitas dan uji homogenitas. Untuk menguji sebaran data berdistribusi normal atau tidak, digunakan uji One Sample Kolmogorov Smirnov dalam program Statistical Product and Service Solutions (SPSS) 19.0. Perolehan hasil uji dengan ketentuan: data sampel berdistribusi normal apabila signifikansi $>0,05$. Namun, apabila signifikansi $<0,05$ maka data sampel tidak berdistribusi normal. Uji homogenitas (kesamaan varian) untuk mengetahui homogen atau tidaknya sampel yang dipilih secara acak dari populasi, sehingga di- 
gunakan uji F (Levene's Test) dalam program Statistical Product and Service Solutions (SPSS) 19.0. Data sampel homogen apabila perolehan signifikansi $>0,05$. Sebaliknya, apabila signifikansi < 0,05 maka data sampel tidak homogen. Selanjutnya, data dihitung dengan menggunakan independent sample t-test. Perhitungan uji $\mathrm{t}$ ini dengan menggunakan program Statistical Product and Service Solutions (SPSS) 19.0.

\section{HASIL DAN PEMBAHASAN}

\section{Hasil Pengembangan}

Tahap ini meliputi observasi lokasi penelitian, menindaklanjuti analisis kebutuhan guru terkait dengan media yang dibutuhkan berdasarkan hasil observasi, wawancara, dan studi pustaka, menyusun garis-garis besar isi dari media serta menjabarkannya ke dalam rancangan media berupa story board, membuat flow chart sebagai gambaran umum rancangan pembuatan multimedia lectora dengan subtema hebatnya cita-citaku. Tahap berikutnya adalah penilaian/uji kelayakan oleh ahli (expert judgement). Uji kelayakan produk dilakukan oleh ahli materi dan ahli media. Penilaian produk oleh ahli media didasarkan pada beberapa aspek, antara lain: Pengembangan produk multimedia lectora ditinjau menurut beberapa aspek, antara lain: (1) komunikasi; (2) desain; dan (3) format sajian. Untuk ahli materi dilihat dari aspek kurikulum dan isi materi. Alur multimedia lectora adalah intro, home, materi pengalaman belajar, dan evaluasi.

Data hasil penilaian ahli media dan ahli materi yang berupa skor kemudian dikonversikan menjadi skala lima. Secara rinci, hal ini dapat dilihat pada Tabel 3.

Produk multimedia lectora yang dibuat telah divalidasi oleh ahli media, dan dinyatakan "layak digunakan dengan revisi". Pada aspek komunikasi layak digu- nakan dengan kategori "Baik" mendapatkan jumlah nilai sebanyak 19. Aspek desain layak digunakan dengan kategori "Sangat Baik" mendapatkan jumlah nilai sebanyak 41. Terakhir adalah aspek format sajian layak digunakan dengan kategori "Sangat Baik" mendapat nilai sebanyak 9. Berdasarkan aspek-aspek tersebut, secara keseluruhan hasil penilaian kelayakan multimedia lectora oleh ahli media mendapatkan total nilai sebanyak 69 dengan kategori "Sangat Baik".

\section{Tabel 3. Penilaian Ahli Media Produk Multimedia Lectora}

\begin{tabular}{lcccc}
\hline No & $\begin{array}{c}\text { Sub } \\
\text { Variabel }\end{array}$ & $\begin{array}{c}\text { Hasil } \\
\text { Penilaian }\end{array}$ & Nilai & Kategori \\
\hline 1. Komunikasi & 19 & B & Baik \\
2. Desain & 41 & A & Sangat Baik \\
3. Format sajian & 9 & A & Sangat Baik \\
$\quad$ Skor Total & 69 & A & Sangat Baik \\
\hline
\end{tabular}

Hasil validasi ahli materi tentang materi pembelajaran yang dinilai dari aspek kurikulum dan isi materi disajikan dalam Tabel 4.

Tabel 4. Penilaian Ahli Materi Produk Multimedia Lectora

\begin{tabular}{clccc}
\hline No. & Sub Variabel & $\begin{array}{c}\text { Hasil } \\
\text { Penilaian }\end{array}$ & Nilai & Kategori \\
\hline 1 & Kurikulum & 45 & A & Sangat Baik \\
2 & Isi Materi & 40 & A & Sangat Baik \\
& Skor Total & 85 & A & Sangat Baik \\
\hline
\end{tabular}

Tabel 4 memperlihatkan bahwa aspek kurikulum mendapatkan nilai 45 dengan kategori "Sangat Baik". Aspek isi materi mendapatkan nilai 40 dengan kategori kelayakan "Sangat Baik". Berdasarkan penilaian tersebut produk multimedia lectora yang dikembangkan jika dinilai dari aspek materi dapat dinyatakan layak untuk digunakan. 


\section{Hasil Uji Coba Produk}

\section{Uji Coba Terbatas}

Uji coba terbatas dilaksanakan selama 2 kali pertemuan dengan subjek coba sebanyak 6siswa kelas IV SD N Grogol. Pemilihan subjek coba ini diambil secara acak dengan memperhatikan perbedaan kemampuan siswa berdasarkan saran dan masukan dari guru kelas. Uji coba terbatas bertujuan untuk mengumpulkan informasi sebagai bahan revisi perbaikan produk multimedia lectora yang dikembangkan serta mengamatiaktivitas dan karakter yang muncul pada diri siswa selama pembelajaran berlangsung. Informasi yang diperoleh dalam uji coba terbatas diolah dan dikumpulkan menjadi data prestasi belajar kognitif siswa, lembar observasi siswa, angket respons guru, dan angket respons siswa.

Kegiatan akhir dalam pembelajaran adalah evaluasi yang dilaksanakan pada pertemuan ke-6. Evaluasi bertujuan untuk mengetahui kemampuan siswa dalam menguasai kompetensi yang sudah ditetapkan di dalam tujuan pembelajaran sebelumnya. Evaluasi disajikan melalui multimedia lectora dan nilai KKM (Kriteria Ketuntasan Minimum) di SD N Grogol ditetapkan sebesar 70 .

Tabel 5. Daftar Skor Hasil Belajar Siswa pada Uji Coba Terbatas

\begin{tabular}{cccc}
\hline No. & $\begin{array}{c}\text { Subjek } \\
\text { Coba }\end{array}$ & Nilai & $\begin{array}{c}\text { Kategori } \\
(\text { KKM 70,00) }\end{array}$ \\
\hline 1 & IRF & 80 & Tuntas \\
2 & AMN & 80 & Tuntas \\
3 & IDP & 67 & Belum Tuntas \\
4 & KP & 73 & Tuntas \\
5 & MSU & 93 & Tuntas \\
6 & PMK & 80 & Tuntas \\
\multicolumn{2}{c}{ Rata-rata } & 78,83 & Tuntas \\
\hline
\end{tabular}

Tabel 5 menunjukkan nilai tertinggi prestasi belajar kognitif siswa diperoleh dengan nilai 93 dan nilai terendah adalah 67 .
Terdapat 5 siswa yang mencapai ketuntasan belajar dan satu siswa yang belum tuntas. Rerata nilai hasil belajar siswa yang dicapai di atas KKM yaitu sebesar 78,83.

Penilaian lembar observasi siswa didasarkan pada karakter siswa yang muncul ketika siswa melakukan kegiatan pembelajaran menggunakan multimedia lectora. Adapun karakter yang ingin dimunculkan di dalam penelitian ini adalah karakter tanggung jawab dan disiplin. Berikut ini adalah data hasil observasi siswa pada uji coba terbatas dapat dilihat pada Tabel 6 .

Tabel 6. Penilaian Hasil Observasi Siswa pada Uji Coba Terbatas Karakter Tanggung Jawab

\begin{tabular}{ccccc}
\hline No. & $\begin{array}{c}\text { Subjek } \\
\text { Coba }\end{array}$ & $\begin{array}{c}\text { Indikator } \\
\text { Tanggung } \\
\text { Jawab }\end{array}$ & Nilai & Kategori \\
\hline 1. & IRF & 34 & B & Baik \\
2. & AMN & 30 & C & Cukup Baik \\
3. & IDP & 33 & B & Baik \\
4. & KP & 35 & B & Baik \\
5. & MSU & 37 & B & Baik \\
6. & PMK & 35 & B & Baik \\
\hline
\end{tabular}

Tabel 7. Penilaian Hasil Observasi Siswa pada Uji Coba TerbatasKarakter Disiplin

\begin{tabular}{ccccc}
\hline No. & $\begin{array}{c}\text { Subjek } \\
\text { Coba }\end{array}$ & $\begin{array}{c}\text { Indikator } \\
\text { Disiplin }\end{array}$ & Nilai & Kategori \\
\hline 1. & IRF & 46 & A & Sangat Baik \\
2. & AMN & 34 & B & Baik \\
3. & IDP & 40 & B & Baik \\
4. & KP & 33 & B & Baik \\
5. & MSU & 35 & B & Baik \\
6. & PMK & 40 & B & Baik \\
\hline
\end{tabular}

Tabel 7 merupakan data hasil observasi terhadap karakter disiplin. Dari data tersebut dapat dilihat bahwa terdapat 5 siswa yang memperoleh nilai B dengan kategori "Baik", dan satu orang siswa yang memperoleh nilai A dengan kategori “Sa- 
ngat Baik". Skor total hasil observasi karakter siswa dapat dilihat dalam Tabel 8.

Tabel 8. Total Skor Hasil Observasi Siswa pada Uji Coba Terbatas

\begin{tabular}{ccccc}
\hline No. & $\begin{array}{c}\text { Subjek } \\
\text { Coba }\end{array}$ & $\begin{array}{c}\text { Skor Total } \\
\text { Nilai } \\
\text { Karakter }\end{array}$ & Nilai & Kategori \\
\hline 1. & IRF & 80 & B & Baik \\
2. & AMN & 64 & C & Cukup Baik \\
3. & IDP & 73 & B & Baik \\
4. & KP & 68 & B & Baik \\
5. & MSU & 72 & B & Baik \\
6. & PMK & 75 & B & Baik \\
\hline
\end{tabular}

Tabel 8 menyajikan data bahwa karakter tanggung jawab dan disiplin sudah mulai muncul dalam pembelajaran dengan multimedia lectora. Terdapat 5 siswa yang memperoleh skor dengan nilai B terkategori "Baik", sedangkan satu siswa memperoleh nilai C terkategori "Cukup Baik". Secara klasikal, dalam uji coba terbatas karakter yang diinginkan oleh peneliti sudah muncul dalam pembelajaran dengan menggunakan multimedia lectora. Hal ini dilihat dari ketercapaian 5 dari 6 siswa memperoleh nilai dengan kategori baik.

Angket respons guru digunakan untuk mengetahui kebermanfaatan penggunaan multimedia lectora dalam pembelajaran.

Tabel 9. Penilaian Hasil Angket Respons Guru pada Uji Coba Terbatas

\begin{tabular}{llccc}
\hline No & Sub Variabel & $\begin{array}{c}\text { Hasil } \\
\text { Penilaian }\end{array}$ & Nilai & Kategori \\
\hline 1. & $\begin{array}{l}\text { Materi Pembe- } \\
\text { lajaran }\end{array}$ & 20 & C & $\begin{array}{c}\text { Cukup } \\
\text { Baik }\end{array}$ \\
2. $\begin{array}{l}\text { Strategi Pem- } \\
\text { belajaran }\end{array}$ & 19 & B & Baik \\
3. $\begin{array}{l}\text { Kualitas Teknis } \\
\text { Skor Total }\end{array}$ & 22 & B & Baik \\
& 61 & B & Baik \\
\hline
\end{tabular}

Tabel 9 menunjukkan respons guru terhadap penggunaan multimedia lectora dalam pembelajaran sudah baik. Ini dapat dilihat dari perolehan nilai yang diberikan oleh guru, yaitu mendapatkan nilai B dengan kategori 'Baik'. Dengan rincian pada subvariabel materi pembelajaran memperoleh nilai C dengan kategori 'Cukup Baik', sub variabel strategi pembelajaran mendapat nilai B dengan kategori 'Baik', dan pada sub variabel kualitas teknis memperoleh nilai B dengan kategori 'Baik'.

Angket respons siswa ini terkait dengan penggunan multimedia lectora di dalam pembelajaran yang telah dilakukan.

\section{Tabel 10. Penilaian HasilAngket Respons Siswa pada Uji Coba Terbatas}

\begin{tabular}{cccc}
\hline No. & Subjek Coba & Nilai & Presentase \\
\hline 1. & IRF & 12 & $80 \%$ \\
2. & AMN & 14 & $73,3 \%$ \\
3. & IDP & 12 & $80 \%$ \\
4. & KP & 14 & $93,3 \%$ \\
5. & MSU & 11 & $93,3 \%$ \\
6. & PMK & 12 & $80 \%$ \\
\hline \multicolumn{3}{c}{ Rata-rata } & $83,31 \%$ \\
\hline
\end{tabular}

\section{Uji Coba Lapangan}

Uji coba lapangan dilakukan dengan subjek coba 12 siswa kelas IV SDN Grogol. Data pada uji coba lapangan meliputi data hasil pelaksanaan pembelajaran yang dilakukan oleh guru maupun siswa, angket guru, angket siswa, observasi siswa, dan tes hasil belajar. Pemilihan subjek uji coba dilakukan secara acak dengan memperhatikan perbedaan kemampuan siswa. Kemampuan siswa dikelompokkan menjadi tinggi, sedang, dan rendah. Dari kelompok tersebut diklasifikasikan sebagia berikut: kemampuan tinggi 4 anak, kemampuan sedang 4 anak, dan kemampuan rendah 4 anak.

Tujuan dilaksanakan uji coba lapangan adalah untuk mengimplementasikan 
produk hasil revisi dan evaluasi berdasarkan hasil uji coba terbatas. Uji coba tersebut juga mengumpulkan informasi yang dapat digunakan sebagai bahan untuk evaluasi dan penyempurnaan produk dalam revisi berikutnya. Informasi yang diperoleh dalam uji coba lapangan diolah dan dikumpulkan menjadi data seperti data observasi guru, observasi siswa, dan data hasil belajar. Analisis dari masing-masing data tersebut dapat dilihat pada Tabel 11.

Tabel 11. Daftar Skor Hasil Belajar Siswa pada Uji Coba Lapangan

\begin{tabular}{cccc}
\hline No & $\begin{array}{c}\text { Subjek } \\
\text { Coba }\end{array}$ & Nilai & $\begin{array}{c}\text { Kategori } \\
(\text { KKM 70,0) }\end{array}$ \\
\hline 1. & IRF & 93 & Tuntas \\
2. & AMN & 80 & Tuntas \\
3. & IDP & 80 & Tuntas \\
4. & KP & 83 & Tuntas \\
5. & MSU & 80 & Tuntas \\
6. & PMK & 73 & Tuntas \\
7. & NFN & 67 & Belum Tuntas \\
8. & KHO & 80 & Tuntas \\
9. & AES & 80 & Tuntas \\
10. & DF & 93 & Tuntas \\
11. & NRA & 80 & Tuntas \\
12. & SNA & 93 & Tuntas \\
\hline \multicolumn{5}{c}{ Rata-rata } & 81,83 & Tuntas \\
\hline
\end{tabular}

Berdasarkan Tabel 11 dapat diketahui bahwa nilai tertinggi hasil belajar siswa diperoleh dengan nilai 93 dan nilai terendah diperoleh dengan nilai 67. Sedangkan KKM yang diharapkan adalah diatas 70 dengan perolehan rerata nilai uji coba lapangan sebesar 81,83 .

Data hasil observasi karakter tanggung jawab yang dilakukan ketika pelaksanaan pembelajaran dengan menggunakan multimedia lectora terhadap 12 siswa. Hasil observasi dapat dilihat pada Tabel 12.

Data pada Tabel 12 menunjukkan bahwa terdapat 5 siswa yang memperoleh nilai A dengan kategori 'Sangat Baik' dan 7 siswa yang memperoleh nilai B dengan kategori 'Baik'. Jika dilihat secara keseluruhan karakter tanggung jawab ini sudah berkembang dengan baik.

\section{Tabel 12. Penilaian Hasil Observasi Siswa pada Uji Coba Lapangan Karak- ter Tanggung jawab}

\begin{tabular}{ccccc}
\hline No & $\begin{array}{c}\text { Subjek } \\
\text { Coba }\end{array}$ & $\begin{array}{c}\text { Skor Total } \\
\text { Nilai } \\
\text { Karakter }\end{array}$ & Nilai & Kategori \\
\hline 1. & IRF & 82 & B & Baik \\
2. & AMN & 99 & A & Sangat Baik \\
3. & IDP & 79 & B & Baik \\
4. & KP & 80 & B & Baik \\
5. & MSU & 82 & B & Baik \\
6. & PMK & 91 & A & Sangat Baik \\
7. & NFN & 90 & A & Sangat Baik \\
8. & KHO & 75 & B & Baik \\
9. & AES & 86 & A & Sangat Baik \\
10. & DF & 88 & A & Sangat Baik \\
11. & NRA & 83 & B & Baik \\
12. & SNA & 82 & B & Baik \\
\hline
\end{tabular}

Observasi siswa yang kedua adalah untuk mengamati karaker disiplin yang muncul pada siswa. Data hasil observasi karakter disiplin siswa dapat dilihat pada Tabel 13.

\section{Tabel 13. Penilaian Hasil Observasi Siswa pada Uji Coba Lapangan Karak- ter Disiplin}

\begin{tabular}{ccccc}
\hline No & $\begin{array}{c}\text { Subjek } \\
\text { Coba }\end{array}$ & $\begin{array}{c}\text { Indikator } \\
\text { Disiplin }\end{array}$ & Nilai & Kategori \\
\hline 1. & IRF & 47 & A & Sangat Baik \\
2. & AMN & 44 & A & Sangat Baik \\
3. & IDP & 41 & B & Baik \\
4. & KP & 37 & B & Baik \\
5. & MSU & 40 & B & Baik \\
6. & PMK & 45 & A & Sangat Baik \\
7. & NFN & 49 & A & Sangat Baik \\
8. & KHO & 37 & B & Baik \\
9. & AES & 44 & A & Sangat Baik \\
10. & DF & 44 & A & Sangat Baik \\
11. & NRA & 45 & A & Sangat Baik \\
12. & SNA & 45 & A & Sangat Baik \\
\hline
\end{tabular}


Berdasarkan Tabel 13 dapat dilihatbahwa karakter disiplin sudah muncul dalam diri siswa. Terdapat 8 siswa yang memperoleh nilai A dengan kategori 'Sangat Baik' dan 4 siswa lainnya memperoleh nilai B dengan kategori 'Baik'. Jika dilihat secara keseluruhan karakter disiplin ini sudah berkembang dengan sangat baik dalam diri siswa. Skor total karakter siswa tersebut dapat dilihat dalam Tabel 14.

Tabel 14. Total Skor Hasil Observasi Siswa pada Uji Coba Lapangan

\begin{tabular}{ccccc}
\hline No. & $\begin{array}{c}\text { Subjek } \\
\text { Coba }\end{array}$ & $\begin{array}{c}\text { Indikator } \\
\text { Tanggung } \\
\text { Jawab }\end{array}$ & Nilai & Kategori \\
\hline 1. & IRF & 35 & B & Baik \\
2. & AMN & 45 & A & Sangat Baik \\
3. & IDP & 38 & B & Baik \\
4. & KP & 43 & B & Baik \\
5. & MSU & 40 & A & Sangat Baik \\
6. & PMK & 44 & A & Sangat Baik \\
7. & NFN & 41 & B & Baik \\
8. & KHO & 38 & B & Baik \\
9. & AES & 42 & A & Sangat Baik \\
10. & DF & 44 & A & Sangat Baik \\
11. & NRA & 38 & B & Baik \\
12. & SNA & 37 & B & Baik \\
\hline
\end{tabular}

Dari Tabel 14 diperoleh hasil bahwa terdapat 7 siswa yang memperoleh skor dengan nilai B terkategori 'Baik', sedangkan 5 siswa memperoleh nilai A terkategori “Sangat 'Baik'. Secara klasikal, dalam uji coba terbatas karakter yang diinginkan oleh peneliti sudah muncul dalam pembelajaran dengan menggunakan multimedia lectora. Hal ini dilihat dari ketercapaian 7 dari 12 siswa memperoleh nilai dengan kategori baik.
Tabel 15. Hasil Penilaian Angket Respons Guru pada Uji Coba Lapangan

\begin{tabular}{lccc}
\hline No Sub Variabel & $\begin{array}{c}\text { Hasil } \\
\text { Penilaian }\end{array}$ & Nilai & Kategori \\
\hline $\begin{array}{l}\text { 1. Materi Pembe- } \\
\text { lajaran }\end{array}$ & 22 & B & Baik \\
$\begin{array}{l}\text { 2. Strategi Pembe- } \\
\text { lajaran }\end{array}$ & 20 & B & Baik \\
$\begin{array}{l}\text { 3. Kualitas Teknis } \\
\quad 25\end{array}$ & B & Baik \\
$\quad$ Skor Total & 67 & B & Baik \\
\hline
\end{tabular}

Berdasarkan Tabel 15 respons guru pada terhadap penggunaan multimedia lectora dalam pembelajaran sudah baik. Hal ini dilihat dari perolehan nilai yang diberikan oleh guru, yaitu mendapatkan nilai B dengan kategori 'Baik'. Dengan rincian pada sub variabel materi pembelajaran memperoleh nilai B dengan kategori 'Baik', sub variabel strategi pembelajaran mendapat nilai B dengan kategori 'Baik', dan pada sub variabel kualitas teknis memperoleh nilai B dengan kategori 'Baik'.

Angket respons siswa ini dilihat dari segi media, materi, dan karakter yang terbentuk. Data hasil angket respons siswa terhadap penggunaan multimedia lectora dapat dilihat dalam Tabel 16 berikut.

Tabel 16. Penilaian HasilAngket Respons Siswa pada Uji Coba Lapangan

\begin{tabular}{cccc}
\hline No & Subjek Coba & Nilai & Presentase \\
\hline 1. & IRF & 14 & $93,3 \%$ \\
2. & AMN & 13 & $86,6 \%$ \\
3. & IDP & 9 & $60 \%$ \\
4. & KP & 10 & $66,6 \%$ \\
5. & MSU & 15 & $100 \%$ \\
6. & PMK & 12 & $80 \%$ \\
7. & NFN & 14 & $93,3 \%$ \\
8. & KHO & 13 & $86,6 \%$ \\
9. & AES & 9 & $60 \%$ \\
10. & DF & 13 & $86,6 \%$ \\
11. & NRA & 11 & $73,3 \%$ \\
12. & SNA & 13 & $86,6 \%$ \\
\hline \multicolumn{4}{r}{}
\end{tabular}




\section{Uji Coba Operasional}

Data pada uji coba operasional meliputi data hasil pelaksanaan pembelajaran yang dilakukan oleh guru maupun siswa, observasi guru, observasi siswa, angket respons guru, angket respons siswa dan tes hasil belajar. Uji coba operasional dilaksanakan di SD N Grogol dengan 22 siswa kelas IV A sebagai kelas eksperimen dan 24 siswa kelas IV B sebagai kelas kontrol. Tujuan uji coba operasional adalah untuk mengimplementasikan produk hasil revisi dan evaluasi berdasarkan hasil uji coba lapangan. Analisis dari masing-masing data tersebut dapat dilihat pada Tabel 17.

Tabel 17. Daftar Skor Pre-Test Prestasi Belajar Kognitif Siswa pada Kelas Kontrol

\begin{tabular}{|c|c|c|}
\hline No. & $\begin{array}{c}\text { Kategori } \\
(\text { KKM 70,0) }\end{array}$ & Jumlah Siswa \\
\hline 1 & Tuntas & 5 \\
\hline & Tidak Tuntas & 19 \\
\hline Nila & ii Terendah & 47 \\
\hline Nila & ii Tertinggi & 80 \\
\hline Nila & ii Rata-rata & 61,42 \\
\hline Kate & egori Ketuntasan & Tidak Tuntas \\
\hline
\end{tabular}

Berdasarkan Tabel 17 dapat diketahui bahwa nilai tertinggi hasil belajar siswa diperoleh dengan nilai 80 dan nilai terendah diperoleh dengan nilai 47. Terdapat 5 subjek coba yang memiliki nilai tuntas. Rerata nilai hasil belajar siswa yang dicapai adalah 61,42 dengan standar deviasi sebesar 9,76 . Selain pelaksanaan pre-test juga dilaksanakan post-test pada kelas kontrol.

Perolehan nilai post-test dapat dilihat pada Tabel 18. Nilai tertinggi prestasi belajar kognitif siswa pada post-test diperoleh dengan nilai 87 dan nilai terendah dengan nilai 60. Terdapat 7 siswa yang memiliki nilai di bawah KKM. Rerata nilai hasil belajar siswa yang dicapai adalah 73,08 dengan standar deviasi sebesar 8,22.
Tabel 18. Daftar Skor Post-Test Prestasi Belajar Kognitif Siswa pada Kelas Kontrol

\begin{tabular}{lcc}
\hline No. & Kategori (KKM & Jumlah Siswa \\
\multicolumn{1}{c}{$70,0)$} & \\
\hline 1 & Tuntas & 17 \\
Nilai Terendah & 7 \\
Nilai Tertinggi & 60 \\
Nilai Rata-rata & 87 \\
Kategori Ketuntasan & 73,08 \\
\hline
\end{tabular}

Data penelitian di kelas eksperimen adalah hasil pre-test dan post-test. Untuk keperluan penelitian, hasil pre-test dan posttest diambil sebanyak 22 siswa. Hasil pretest di kelas eksperimen dapat dilihat pada Tabel 19.

Tabel 19. Daftar Skor Pre-Test Prestasi Belajar Kognitif Siswa pada Kelas Eksperimen

\begin{tabular}{lcc}
\hline \multirow{2}{*}{ No. } & $\begin{array}{c}\text { Kategori (KKM } \\
70,0)\end{array}$ & Jumlah Siswa \\
\hline 1 & Tuntas & 6 \\
2 & Tidak Tuntas & 16 \\
Nilai Terendah & 47 \\
Nilai Tertinggi & 80 \\
Nilai Rata-rata & 64,81 \\
Kategori Ketuntasan & Belum Tuntas \\
\hline
\end{tabular}

Dari Tabel 19 diketahui bahwa nilai tertinggi hasil belajar siswa diperoleh dengan nilai 80 dan nilai terendah diperoleh dengan nilai 47. Terdapat 6 siswa yang sudah tuntas karena memperoleh nilai di atas KKM. Rerata nilai hasil belajar siswa yang dicapai adalah 64,81 dengan standar deviasi sebesar 8,98 .

Tes yang kedua adalah post-test yang dilakukan pada kelas eksperimen. Untuk perolehan nilai post-test pada kelas eksperimen dapat dilihat dalam Tabel 20. 
Tabel 20. Daftar Skor Post-Test Prestasi Belajar Kognitif Siswa pada Kelas Eksperimen

\begin{tabular}{lcc}
\hline No. & Kategori (KKM & Jumlah Siswa \\
\hline $1 \quad$ Tuntas & 22 \\
2 & Tidak Tuntas & 0 \\
Nilai Terendah & 73 \\
Nilai Tertinggi & 93 \\
Nilai Rata-rata & 83,23 \\
Kategori Ketuntasan & Tuntas \\
\hline
\end{tabular}

Berdasarkan Tabel 20 diketahui bahwa nilai tertinggi hasil belajar siswa diperoleh dengan nilai 93 dan nilai terendah diperoleh dengan nilai 73. Siswa tergolong sudah tuntas semua karena memenuhi KKM sebesar 70. Rerata nilai hasil belajar siswa yang dicapai adalah 83,23 dengan standar deviasi sebesar 7,94.

Tabel 21. Penilaian Hasil Observasi Siswa pada Uji Coba Operasional Karakter Tanggung Jawab pada Kelas Kontrol

\begin{tabular}{|c|c|c|c|c|}
\hline No & Hasil Penilaian & Nilai & Kategori & $\begin{array}{c}\text { Jumlah } \\
\text { Siswa }\end{array}$ \\
\hline 1. & $x>42,06$ & A & Sangat Baik & 3 \\
\hline 2. & $34,02<x \leq 42,06$ & B & Baik & 19 \\
\hline 3. & $25,98<x \leq 34,02$ & $\mathrm{C}$ & Cukup Baik & 1 \\
\hline 4. & $17,94<x \leq 25,98$ & $\mathrm{D}$ & Kurang Baik & 0 \\
\hline 5. & $x \leq 17,94$ & E & Tidak Baik & 0 \\
\hline \multicolumn{4}{|c|}{ Jumlah } & 24 \\
\hline
\end{tabular}

Pada Tabel 21 dapat dilihat dari 24 siswa terdapat 1 siswa yang memperoleh nilai C dengan kategori 'Cukup Baik', 19 siswa yang memperoleh nilai $\mathrm{B}$ dengan kategori 'Baik', dan 3 siswa dengan nilai A dengan kategori 'Sangat Baik'. Secara keseluruhan perolehan nilai karakter tanggung jawab belum sepenuhnya baik. Observasi siswa yang kedua adalah untuk mengamati karaker disiplin yang muncul pada siswa. Data dari hasil observasi karakter disiplin siswa.
Tabel 22. Penilaian Hasil Observasi Siswa pada Uji Coba Operasional Karakter Disiplin pada Kelas Kontrol

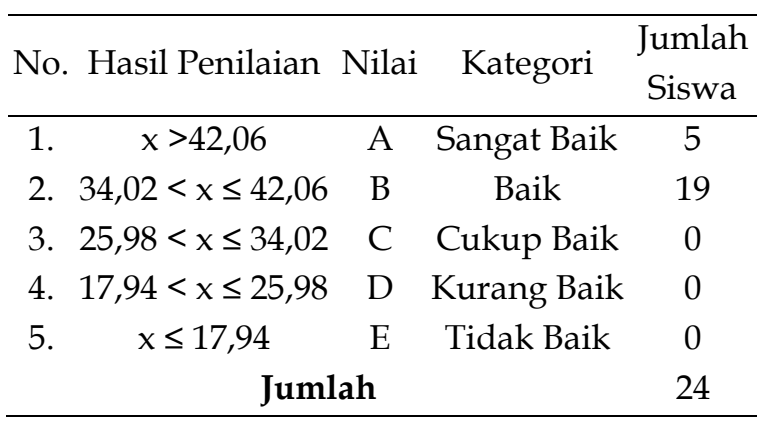

Pada Tabel 22 menyajikan data karakter disiplin pada kelas kontrol. Dari tabel diperoleh hasil terdapat 19 siswa yang memperoleh nilai B terkategori 'Baik', sedangkan 5 siswa memperoleh nilai $\mathrm{A}$ terkategori "Sangat 'Baik'. Berdasarkan kedua hal di atas, skor total observasi karakter siswa pada uji coba operasional pada kelas kontrol dapat dilihat pada Tabel 23.

Tabel 23. Total Skor Penilaian Hasil Observasi Siswa pada Uji Coba Operasional pada Kelas Kontrol

\begin{tabular}{lccc}
\hline No. Hasil Penilaian Nilai & Kategori & $\begin{array}{c}\text { Jumlah } \\
\text { Siswa }\end{array}$ \\
\hline $1 . x>42,06$ & A & Sangat Baik & 10 \\
$2.34,02<x \leq 42,06$ & B & Baik & 12 \\
$3.25,98<x \leq 34,02$ & C & Cukup Baik & 0 \\
$4.17,94<x \leq 25,98$ & D & Kurang Baik & 0 \\
$5 . x \leq 17,94$ & E & Tidak Baik & 0 \\
& Jumlah & & 22 \\
\hline
\end{tabular}

Tabel 23 menyajikan data hasil pengamatan terhadap karakter tanggung jawab dan disiplin pada siswa kelas kontrol yang diperoleh hasil bahwa terdapat 17 siswa yang memperoleh skor dengan nilai B terkategori 'Baik', sedangkan 7 siswa memperoleh nilai A terkategori “Sangat 'Baik'.

Kelas eksperimen dalam penelitian ini adalah kelas IVA. Pada kelas ini diberikan perlakuan berupa pembelajaran dengan menggunakan multimedia lectora se- 
bagai media pembelajaran. Kelas eksperimen dalam penelitian ini adalah siswa kelas IV terdiri dari 22 siswa. Selama pembelajaran, siswa diberikan materi melalui multimedia lectora ini. Siswa dibimbing guru dalam pengoperasiaan multimedia lectora. Siswa diberi kesempatan untuk memegang komputer masing-masing. Guru memberikan petunjuk penggunaan lectora dan bersama dengan siswa memulai pembelajaran dari pembelajaran 1 sampai dengan pembelajaran 6 dan dilanjutkan dengan melaksanakan evaluasi. Selama proses pembelajaran berlangsung, guru melakukan pengamatan terhadap karakter yang dikembangkan. Berikut adalah data hasil observasi pada uji coba operasional pada kelas eksperimen.

Tabel 24. Penilaian Hasil Observasi Siswa pada Uji Coba Operasional Karakter Tanggung jawab pada Kelas Eksperimen

\begin{tabular}{|c|c|c|c|}
\hline No Hasil Penilaian & Nilai & Kategori & $\begin{array}{c}\text { Jumlah } \\
\text { Siswa }\end{array}$ \\
\hline 1. $x>42,06$ & A & Sangat Baik & 7 \\
\hline 2. $34,02<x \leq 42,06$ & B & Baik & 17 \\
\hline 3. $25,98<x \leq 34,02$ & C & Cukup Baik & 0 \\
\hline 4. $17,94<x \leq 25,98$ & $\mathrm{D}$ & Kurang Baik & 0 \\
\hline 5. $x \leq 17,94$ & $\mathrm{E}$ & Tidak Baik & 0 \\
\hline & 24 \\
\hline
\end{tabular}

Tabel 24 menunjukkan terdapat 10 siswa yang memperoleh nilai B dengan kategori 'Baik', dan 12 siswa yang memperoleh nilai A dengan kategori 'Sangat Baik'. Secara keseluruhan perolehan nilai karakter tanggung jawab pada kelas eksperimen sepenuhnya baik.

Observasi siswa yang kedua adalah untuk mengamati karakter disiplin yang muncul pada siswa. Data dari hasil observasi karakter disiplin siswa dapat dilihat pada Tabel 25.

\section{Tabel 25. Penilaian Hasil Observasi Siswa pada Uji Coba Operasional Ka- rakter Disiplin pada Kelas Eks- perimen}

\begin{tabular}{lrcc}
\hline No Hasil Penilaian & Nilai & Kategori & $\begin{array}{c}\text { Jumlah } \\
\text { Siswa }\end{array}$ \\
\hline $1 . x>42,06$ & A & Sangat Baik & 18 \\
$2.34,02<x \leq 42,06$ & B & Baik & 4 \\
3. $25,98<x \leq 34,02$ & C & Cukup Baik & 0 \\
4. $17,94<x \leq 25,98$ & D & Kurang Baik & 0 \\
5. $x \leq 17,94$ & E & Tidak Baik & 0 \\
& Jumlah & & 22 \\
\hline
\end{tabular}

Pada Tabel 25 tersebut dapat dilihat bahwa terdapat 4 siswa yang memperoleh nilai B dengan kategori 'Baik', dan 18 siswa memperoleh nilai A dengan kategori 'Sangat Baik'. Secara keseluruhan perolehan nilai karakter disiplin pada kelas eksperimen sepenuhnya baik. Hal tersebut terlihat dari perolehan nilai yang didapat selama pengamatan dari 22 siswa terdapat 18 siswa yang memiliki nilai dengan kategori sangat baik.

Berdasarkan kedua hal di atas, dapat dilihat skor total yang didapatkan selama observasi pada uji coba operasional di kelas eksperimen seperti berikut.

Tabel 26. Total Skor Penilaian Hasil Observasi Siswa pada Uji Coba Operasional pada Kelas Eksperimen

\begin{tabular}{clccc}
\hline No & Hasil Penilaian & Nilai & Kategori & $\begin{array}{c}\text { Jumlah } \\
\text { Siswa }\end{array}$ \\
\hline 1 & $x>42,06$ & A & Sangat Baik & 14 \\
2 & $34,02<x \leq 42,06$ & B & Baik & 8 \\
3 & $25,98<x \leq 34,02$ & C & Cukup Baik & 0 \\
4 & $17,94<x \leq 25,98$ & D & Kurang Baik & 0 \\
5 & $x \leq 17,94 \quad$ Jumlah & E & Tidak Baik & 0 \\
& & & 22 \\
\hline
\end{tabular}

Pada Tabel 26 di atas diajikan data hasil pengamatan terhadap karakter tanggung jawab dan disiplin pada siswa kelas eksperimen, yaitu diperoleh hasil bahwa terdapat 8 siswa yang memperoleh skor dengan nilai B terkategori 'Baik', sedangkan 
14 siswa memperoleh nilai A terkategori “Sangat 'Baik'.

Tabel 27. Penilaian Hasil Angket Respons Guru pada Uji Coba Operasional

\begin{tabular}{llccc}
\hline No & Sub Variabel & $\begin{array}{c}\text { Hasil } \\
\text { Penilaian }\end{array}$ & Nilai & Kategori \\
\hline 1. Materi & 25 & B & Baik \\
$\begin{array}{l}\text { Pembelajaran } \\
\text { Strategi }\end{array}$ & & & \\
2. & Pembelajaran & 23 & A & Sangat Baik \\
3. Kualitas Teknis & 27 & A & Sangat Baik \\
$\quad$ Skor Total & 75 & A & Sangat Baik \\
\hline
\end{tabular}

Berdasarkan Tabel 27, respons guru terhadap penggunaan multimedia lectora dalam pembelajaran sudah baik.

Tabel 28. Penilaian HasilAngket Respons Siswa pada Uji Coba Lapangan

\begin{tabular}{cccc}
\hline No & Subjek Coba & Nilai & Presentase \\
\hline 1. & IRF & 15 & $100 \%$ \\
2. & AMN & 14 & $93,3 \%$ \\
3. & IDP & 14 & $93,3 \%$ \\
4. & KP & 13 & $86,6 \%$ \\
5. & MSU & 13 & $86,6 \%$ \\
6. & PMK & 13 & $86,6 \%$ \\
7. & NFN & 15 & $100 \%$ \\
8. & KHO & 14 & $93,3 \%$ \\
9. & AES & 13 & $86,6 \%$ \\
10. & DF & 15 & $100 \%$ \\
11. & NRA & 11 & $73,3 \%$ \\
12. & SNA & 15 & $100 \%$ \\
13. & LA & 12 & $80 \%$ \\
14. & AH & 15 & $100 \%$ \\
15. & AS & 12 & $80 \%$ \\
16. & RR & 12 & $80 \%$ \\
17. & WHY & 12 & $80 \%$ \\
18. & AZL & 14 & $93,3 \%$ \\
19. & PRA & 13 & $86,6 \%$ \\
20. & DAV & 15 & $100 \%$ \\
22. & BP & 14 & $93,3 \%$ \\
22. & ADS & 11 & $73,3 \%$ \\
& Rata-rata & & $89,36 \%$ \\
\hline & & &
\end{tabular}

Dapat dilihat bahwa berdasarkan Tabel 28 rata-rata respons siswa terhadap penggunaan multimedialectora adalah baik, karena terdapat $89,36 \%$ siswa yang memberikan penilaian yang baik terhadap mul- timedia lectora. Komentar dari siswa menunjukkan respons positif. Terlihat bahwa siswa merasa senang dan mudah mengerti materi yang disampaikan ketika melaksanakan pembelajaran dengan multimedia lectora.

\section{Uji Efektivitas Media}

Uji efektivitas dilakukan dengan desain penelitian quasy experiment. Desain penelitian ini digunakan untuk membandingkan keadaan kelas kontrol dengan kelas eksperimen. Kelas kontrol tidak diberi perlakuan, sedangkan kelas eksperimen diberi perlakuan dengan menggunakan multimedia lectora. Pada penelitian ini dikaji mengenai perbedaan antara siswa yang menggunakan media konvensional (Kelas Kontrol) dengan siswa yang menggunakan multimedia lectora hasil pengembangan (Kelas Eksperimen). Untuk mengetahui ada tidaknya perbedaan karakter siswa pada kedua kelas digunakan analisis uji-t. Sebelum melakukan uji ini diperlukan uji prasyarat analisis, yaitu berupa uji normalitas dan homogenitas. Dengan demikian, normalitas atau homogenitas dipenuhi jika hasil uji tidak signifikan untuk suatu taraf signifikansi $(\alpha)$ tertentu $(\alpha=0,05)$. Sebaliknya, jika hasil uji signifikan maka normalitas atau homogenitas tidak terpenuhi. Berikut analisis hasil pada uji $\mathrm{t}$ (independent sample ttest) pada karakter tanggung jawab dan disiplin yang dikembangkan pada siswa kelas IV SD N Grogol. Berikut data hasil uji normalitas, uji homogenitas, dan uji t pada karakter tanggung jawab dan disiplin.

Uji normalitas dari karakter tanggung jawab menggunakan uji kolmogrov smirnov diperoleh signifikan sebesar 0,765 lebih besar dari probabilitas 0,05. Dengan demikian, $\mathrm{H}_{0}$ diterima atau data tersebut berdistribusi normal. 
Tabel 29. Ringkasan Hasil Uji Homogenitas Karakter Tanggung jawab

\begin{tabular}{lccccl}
\hline \multicolumn{1}{c}{ Data } & $\begin{array}{c}\mathrm{df} \\
1\end{array}$ & $\begin{array}{c}\mathrm{df} \\
2\end{array}$ & $\begin{array}{c}\text { sig. } \\
(\mathrm{p})\end{array}$ & Kondisi & Ket \\
\hline Gain & 4 & 12 & 0,22 & $\mathrm{p}>0,05$ & Homo \\
standar & & & 1 & & gen \\
karakter & & & & & \\
tanggung & & & & & \\
jawab & & & & & \\
\hline
\end{tabular}

Berdasarkan Tabel 29 di atas, terlihat bahwa nilai uji homogenitas memperoleh hasil signifikansi sebesar 0,221 lebih besar dari probabilitas 0,05. Dengan demikian dapat disimpulkan bahwa $\mathrm{H}_{0}$ diterima atau data tersebut bersifat homogen. Karena data berdistribusi normal dan bersifat homogen, maka digunakan uji-t (independent sample t-test). Dalam penelitian ini perhitungan independent sample t-test menggunakan bantuan program SPSSTM. Hasil analisis perbedaan hasil tersebut diuraikan sebagai berikut.

Tabel 30. Ringkasan Hasil Uji-T Karakter Tanggung Jawab

\begin{tabular}{cccccc}
\hline Kelas & Signifikansi & $\mathrm{N}$ & $\mathrm{Df}$ & $\mathrm{P}$ & Ket \\
\hline $\mathrm{KE}$ & 0,104 & 22 & 44 & 0,015 & $\mathrm{H}_{0}$ \\
$\mathrm{~K}$ & & 24 & 36,94 & & ditolak \\
$\mathrm{K}$ & & & 2 & & \\
\hline
\end{tabular}

Terlihat dari hasil penghitungan SPSS 16 dengan probabilitas 0,015. Oleh karena nilai probabilitas adalah $0,015<0,05$ maka Ho ditolak, artinya karakter tanggung jawab antara kelas kontrol dan kelas eksperimen adalah berbeda secara signifykan. Berdasarkan data tersebut menunjukkan bahwa karakter tanggung jawab pada kelas ekperimen lebih baik daripada kelas kontrol.

Uji normalitas dari karakter disiplin menggunakan uji kolmogrov smirnov, diperoleh signifikan sebesar 0,826 yang artinya lebih besar dari probabilitas 0,05 . Dengan demikian dapat dikatakan bahwa $\mathrm{H}_{0}$ diterima atau data tersebut berdistribusi normal.

Tabel 31. Ringkasan Hasil Uji Homogenitas Karakter Disiplin

\begin{tabular}{cccccc}
\hline Data & $\begin{array}{c}\mathrm{df} \\
1\end{array}$ & $\begin{array}{c}\mathrm{df} \\
2\end{array}$ & sig.(p) & Kondisi & Ket \\
\hline $\begin{array}{c}\text { Gain } \\
\text { standar } \\
\begin{array}{c}\text { kakter } \\
\text { disiplin }\end{array}\end{array}$ & 4 & 15 & 0,251 & $\mathrm{p}>0,05$ & $\begin{array}{l}\text { Ho } \\
\text { mo } \\
\text { gen }\end{array}$ \\
\hline
\end{tabular}

Berdasarkan Tabel 31 di atas, terlihat bahwa nilai uji homogenitas dengan hasil signifikansi 0,251 lebih besar dari probabilitas 0,05 . Dengan demikian $\mathrm{H}_{0}$ diterima atau data tersebut bersifat homogen. Karena data yang dihasilkan merupakan data berdistribusi normal dan bersifat homogen maka digunakan uji-t (independent sample ttest). Hasil perhitungan independent sample t-test untuk kedua kelompok ditinjau dari peningkatan karakter siswa dapat dilihat dalam tabel 32.

Tabel 32. Ringkasan Hasil Uji-T Karakter Disiplin

\begin{tabular}{cccccc}
\hline \multicolumn{2}{l}{ Kelas } & Signifikansi N & Df & $\mathrm{P}$ & Ket \\
\hline KE & 0,268 & 22 & 44 & 0,001 & $\mathrm{H}_{0}$ \\
KK & & 24 & 43,98 & & ditolak \\
\hline
\end{tabular}

Terlihat dari hasil penghitungan spss 16 dengan probabilitas 0,001. Karena 0,001 $<$ 0,05 maka Ho ditolak. Artinya, karakter disiplin antara kelas kontrol dan kelas eksperimen adalah berbeda secara signifikan, karakter disiplin pada kelas ekperimen lebih baik daripada kelas kontrol.

Penelitian ini juga mengkaji perbedaan prestasi belajar antara siswa yang menggunakan media konvensional (Kelas Kontrol) dengan siswa yang menggunakan multimedia lectora hasil pengembangan (Kelas Eksperimen). Untuk mengetahui ada tidaknya perbedaan prestasi belajar siswa pada kedua kelas digunakan analisis uji-t. 
Tabel 33. Ringkasan Hasil Uji Normalitas Prestasi Belajar Kognitif

\begin{tabular}{lccc}
\hline \multirow{1}{*}{ Kelas } & $\begin{array}{c}\text { Pre-test } \\
\text { sig.(p) }\end{array}$ & $\begin{array}{c}\text { Post-test } \\
\text { sig.(p) }\end{array}$ & Ket \\
& $>0,05$ & $>0,05$ & \\
\hline Kelas Eksperimen & 0,157 & 0,069 & Tuntas \\
Kelas Kontrol & 0,057 & 0,054 & Tuntas \\
\hline
\end{tabular}

Berdasarkan Tabel 33 di atas, terlihat bahwa nilai uji normalitas dengan hasil signifikansi yang diperoleh lebih besar dari probabilitas 0,05 . Dengan demikian, $\mathrm{H}_{0}$ diterima atau data tersebut berdistribusi normal. Untuk hasil uji homogenitas untuk prestasi belajar kognitif siswa dapat diringkas sebagai berikut.

Tabel 34. Ringkasan Hasil Uji Homogenitas Prestasi Belajar Kognitif

\begin{tabular}{lccccc}
\hline \multicolumn{1}{c}{ Data } & df1 & df2 & sig.(p) & Kondisi & Ket \\
\hline Pre-test & 4 & 16 & 0,73 & $\mathrm{p}>0,05$ & Homogen \\
Post-test & 4 & 15 & 0,124 & $\mathrm{P}>0,05$ & Homogen \\
\hline
\end{tabular}

Terlihat bahwa nilai uji homogenitas dengan hasil signifikansi lebih besar dari probabilitas 0,05 . Dengan demikian, $\mathrm{H}_{0}$ diterima atau data tersebut bersifat homogen. Karena data berdistribusi normal dan bersifat homogen maka digunakan uji-t (independent sample t-test). Dalam penelitian ini perhitungan independent sample t-test. Hasil uji $t$ tersebut dapat dilihat pada Tabel 35.

\section{Tabel 35. Ringkasan Hasil Uji-T Pre-test Prestasi Belajar}

\begin{tabular}{cccccc}
\hline Kelas & $\begin{array}{c}\text { Rerata } \\
\text { skor }\end{array}$ & N & Df & p & Ket \\
\hline KE & 64,82 & 22 & 44 & 0,227 & $\mathrm{H}_{0}$ ditolak \\
KK & 61,42 & 24 & & & \\
\hline
\end{tabular}

Terlihat dari hasil penghitungan SPSS 16 dengan probabilitas 0,227. Karena 0,227 >0,05 maka Ho diterima. Artinya, hasil belajar pada pre-test tidak mengalami perbedaan yang signifikan antara kelas eksperimen dan kelas kontrol.

\begin{tabular}{|c|c|c|c|c|c|}
\hline Kelas & $\begin{array}{c}\text { Rerata } \\
\text { skor }\end{array}$ & $\mathrm{N}$ & Df & $\mathrm{p}$ & Ket \\
\hline $\mathrm{KE}$ & 83,23 & 22 & 44 & 0,000 & $\mathrm{H}_{0}$ \\
\hline KK & 73,08 & 24 & & & ditolak \\
\hline
\end{tabular}

Terlihat dari hasil penghitungan SPSS 16 dengan probabilitas 0,000. Oleh karena itu 0,000 <0,05 maka Ho ditolak. Artinya, hasil belajar pada post-test mengalami perbedaan yang signifikan antara kelas eksperimen dengan kelas kontrol.

\section{Pembahasan}

Multimedia pembelajaran yang dikembangkan dalam penelitian ini layak digunakan dalam pembelajaran tematik-integratif dengan tema cita-citaku subtema hebatnya cita-citaku di kelas IV SD, karena berdasarkan penilaian dari ahli media dan ahli materi, menurut ahli media produk mulitemedia lectora ini mendapat nilai sebesar 69 terkategori"sangat baik", sedangkan menurut ahli materi, dalam multimedia lectora ini mendapatkan nilai sebesar 85 terkategori "sangat baik". Dari hasil penilaian ahli tersebut, dapat dilihat bahwa multimedia lectora ini dinilai mempunyai konsep yang benar, disajikan dengan petunjuk yang jelas, materi sesuai dengan kompetensi dasar dan kompetensi inti, sedangkan pada tampilan desain multimedia lectora dinilai sesuai dengan standar teknis penyajian suatu multimedia yang digunakan di dalam pembelajaran, yaitu memiliki grafis background yang jelas, petujuk penggunaan, gambar-gambar, animasi, musik, teks bacaan, dan audio yang mendukung proses pembelajaran sehingga siswa terlihat senang dan tertarik selama pembelajaran berlangsung. 
Berdasarkan hasil uji coba operasional yang dilakukan pada kelas IVA sebagai kelas eksperimen. Multimedia lectora dinilai mampu meningkatkan aktivitas siswa dan menumbuhkan nilai karakter tanggung jawab dan disiplin pada diri siswa. Selain itu, multimedia lectora juga mampu meningkatkan hasil belajar siswa. Untuk aktivitas siswa yang diamati, pada karakter tanggung jawab terjadi peningkatan.

Rata-rata ketercapaian hasil belajar mengalami peningkatan ditinjau dari skor pre-test dan post-test. Kelas eksperimen mengalami peningkatan lebih tinggi dibanding kelas kontrol. Berdasarkan hasil uji-t, secara statistik terlihat bahwa terdapat perbedaan gain standar hasil belajar antara kelas eksperimen dan kelas kontrol.

\section{Revisi Produk}

Revisi produk multimedia lectora berdasarkan saran dari dosen ahli dan guru. Revisi draf awal dilaksanakan berdasarkan saran dari ahli. Revisi uji coba terbatas, uji coba lapangan, dan uji coba produk operasional dilaksanakan berdasarkan saran dari guru.

Revisi draf awal multimedia lectora berdasarkan saran dan masukan dari dua dosen ahli, yaitu ahli media dengan ahli materi. Revisi dilakukan setelah produk divalidasi. Hal-hal yang perlu direvisi antara lain: (1) suara diperjelas, jangan menggunakan suara yang mengagetkan siswa; (2) tombol fungsi diperbaiki, misalnya diberi tambahan tombol next-back sehingga anak tidak perlu memulai pembelajaran dari awal lagi; (3) pada teks bacaan jangan discroll, lebih baik dilanjutkan ke halaman berikutnya; (4) tokoh yang diambil jangan hanya yang tokoh bukan pribumi, perbaiki dengan mencari tokoh pribumi saja; dan (5) dicek kembali tentang informasi mengenai letak suatu daerah, jelaskan lebih detail lagi mengenai lokasi suatu tempat. Produk hasil draf awal yang telah direvisi kemudian digunakan untuk uji coba terbatas di SD N Grogol.

Tahap kedua adalah merevisi multimedia lectora yang sudah digunakan di dalam uji coba terbatas. Revisi dilakukan berdasarkan saran dari guru. Adapun saran yang diberikan guru adalah: (1) pemberian petunjuk di awal masuk ke menu pembelajaran; (2) pemberian effect sound jika siswa salah menekal tombol; (3) penggunaan teks cerita pada materi jangan terlalu panjang; (4) warna tampilan lectora, background diubah ke warna yang tidak menyilaukan mata siswa. Produk uji coba terbatas yang telah direvisi selanjutnya digunakan untuk uji coba lapangan.

Revisi selanjutnya masih berdasarkan saran dari guru setelah pelaksanaan uji coba lapangan. Hal yang perlu direvisi kembali yaitu: (1) pengaturan musik harus jelas suaranya; (2) tulisan pada teks diperbesar; dan (3) gambar tokoh diperjelas.

\section{Kajian Produk Akhir}

Produk akhir dalam penelitian ini merupakan hasil perbaikan dari revisi draf awal, uji terbatas, dan uji coba lapangan. Produk akhir berupa sebuah multimedia pembelajaran lectora dengan tema Cita-citaku subtema Hebatnya Cita-citaku. Kajian produk akhir yang dihasilkan seperti berikut.(1) Multimedia lectora mempunyai konsep yang benar, disajikan dengan petunjuk yang jelas, materi sesuai dengan kompetensi dasar dan kompetensi inti, tampilan desain multimedia lectora dinilai sesuai dengan standar teknis penyajian suatu multimedia yang digunakan di dalam pembelajaran. (2) Desain multimedia lectora memiliki grafis background yang jelas, petunjuk penggunaan, gambar-gambar, animasi, musik, teks bacaan, dan audio yang men- 
dukung proses pembelajaran sehingga siswa terlihat senang dan tertarik selama pembelajaran berlangsung. (3) Multimedia lectora memberikan latihan soal di setiap kegiatan belajar sehingga dapat dijadikan sebagai alat untuk mengukur pemahaman siswa. (4) Multimedia lectora menyajikan permainan puzzle yang dapat digunakan untuk menarik rasa ingin tahu siswa sehingga siswa dapat menambah pemahamannya terhadap materi yang disampaikan oleh guru. (5) Multimedia lectora mampu meningkatkan aktivitas siswa serta mampu mengembangkan karakter tanggung jawab dan disiplin. (6) Multimedia lectora mampu meningkatkan prestasi belajar siswa. Hal ini dapat dilihat dari nilai siswa yang secara klasikal mencapai ketuntasan 100\%.

\section{PENUTUP}

Berdasarkan penelitian yang telah dilaksanakan, dapat disimpulkan bahwa produk multimedia pembelajaran lectora dengan subtema Hebatnya Cita-citaku di kelas IV Sekolah Dasar yang dikembangkan di dalam penelitian ini dinyatakan layak digunakan di dalam pembelajaran tematik-integratif guna meningkatkan prestasi belajar kognitif dan mengembangkan nilai karakter tanggung jawab dan disiplin. Produk multimedia pembelajaran lectora dengan subtema Hebatnya Cita-citaku di kelas IV Sekolah Dasar yang dikembangkan di dalam penelitian ini juga dinyatakan efektif digunakan dalam pembelajaran tematik-integratif guna meningkatkan prestasi belajar kognitif.

Prestasi belajar kognitif sebelum menggunakan multimedia lectora memperoleh rata-rata sebesar 64,81 dan sesudah menggunakan multimedia lectora mencapai rata-rata sebesar 83,23. Terdapat perbedaan yang signifikan pada efektivitas pembelajaran sebelum dan sesudah menggunakan multimedia lectora, yaitu dapat dilihat berdasarkan uji $t$ dan anova, yang berdasarkan perhitungannya diperoleh harga probabilitas ( $\mathrm{p}$ ) > 0,05 jatuh pada penerimaan Ha atau penolakan Ho. Nilai F pada anova sebesar 1,504 dengan signifikansi 0,244.

Produk multimedia pembelajaran lectora ini juga dinyatakan efektif digunakan dalam pembelajaran tematik-integratif guna meningkatkan karakter tanggung jawab dan disiplin. Hal ini dapat dilihat dari hasil observasi karakter tanggung jawab dan disiplin, yaitu terdapat perbedaan antara kelompok eksperimen dan kelompok kontrol.

\section{UCAPAN TERIMA KASIH}

Penulis mengucapkan terima kasih atas dipublikasikan artikel ini pada edisi sekarang, terutama kepada Ketua Dewan Redaksi Jurnal Pendidikan Karakter. Semoga artikel ini bermanfaat.

\section{DAFTAR PUSTAKA}

Yani, A. (2013). Mindset kurikulum 2013. Bandung: Alfabeta.

Apriani, A., \& Wangid, M. (2015). Pengaruh SSP tematik-integratif terhadap karakter disiplin dan tanggung jawab siswa kelas III SD". Jurnal Prima Edukasia, 3(1), 12-25. Retrieved from http://journal.uny.ac.id/index.php/j pe/article/view/4061.

Bertens, K. (2005). Etika. Jakarta: Gramedia Pustaka Utama.

Borg, W.R. \& Gall, M.D. (1983). Educational research: An introduction (4th ed.). New York: Longman Inc.

DeJong, T, Specht, M., \& Koper, R. (2008). "Contextualised media for learning". Journal of Educational Technology \& Society, 11(2), 41-53. URL: https://- 
www.jstor.org/stable/10.2307/jeduc techsoci.11.2.41.

Fanny, A. \& Suardiman, S. (2013). Pengembangan multimedia interaktif untuk mata pelajaran ilmu pengetahuan sosial (IPS) sekolah dasar kelas V. Jurnal Prima Edukasia, 1 (1), 1-9. Retrieved from http://journal.uny.ac.id/index.php/jpe/article/view/2311.

Fogarty, R. (1991). The mindful school: How to integrate the curricula. Palatine, Illinois: IRI/Skylight Publishing, Inc.

Fredy, F. \& Soenarto, S. (2013). Pengembangan multimedia pembelajaran matematika pada materi bilangan bulat kelas IV SDN Lempuyangan I Yogyakarta. Jurnal Prima Edukasia, 1(2), 162-172. Retrieved from http://journal.uny.ac.id/index.php/jpe/article/ view/2633.

Hamedoglu, Ali, M., \&Hatice, B. (2012). Encountered disclipinary problem in elemantary school of a law socioeconomically status district. Proceedings of Sakarya University, Turkey, 55, 502-511.
Kemendiknas. (2013). Materi pelatihan guru implementasi Kurikulum 2013. Jakarta: Kemendiknas RI.

Mas'ud, M. (2013). Membuat multimedia pembelajaran dengan lectora. Yogyakarta: Pustaka Shonif.

Sudjana, N. (2013). Penilaian hasil proses belajar mengajar. Bandung: Remaja Rosdakarya.

Schunk, H.D. (2008). Learning theories an educational perspective. Boston: Pearson.

Uno. H., \& Lamatenggo. N. (2010). Teknologi komunikasi $\mathcal{E}$ informasi pembelajaran. Jakarta: Bumi Aksara.

Yang, C.C.R. (2009). Theme-based teaching in an english course for primary ESL student in Hong Kong. Electronic Journal of Foreign Language Theaching, 6(2), 161-176. Retrieved from http://eflt.nus.edu.sg/v6n22009/yang.pdf.

Zuchdi, D., Prasetya, Z.K., \& Masruri. S. M. (2009). Model pendidikan karakter: terintegrasi dalam pembelajaran dan pengembangan kultursekolah. Yogyakarta:UNY Press. 